described these rocks, ignimbrites are well represented in the excellent photographs illustrating his Memoir (von Eckermann, 1936, Plate LXIX, fig. 2; Plate LXXI, figs. 1 and 2; Plate LXXII). Here then is evidence that sheets of granophyre are crystallized ignimbrites; Bowen and Tuttle's experimental results, combined with Sabatier's viscosity determinations, provide evidence concerning the physical conditions under which this could happen without true liquefaction.

\title{
REFERENCES
}

ECKermanN, H. von, 1936. The Loos-Hamra region. Geol. Fören. Förhandl., Stockholm, lviii, 129-343.

HJelmovist, S., 1955. On the occurrence of ignimbrite in the Pre-Cambrian. Sverig. Geol. Undersök., xlix, 3-12.

KANI, K., 1934. The measurement of the viscosity of basalt glass at high temperatures, II. Proc. Imper. Acad. of Japan., x, 79-82.

Marshall, P., 1935. Acid rocks of the Taupo-Rotorua volcanic district. Trans. Royal Soc. New Zealand, Ixiv, 1-44.

Reynolds, D. L., 1951. The geology of Slieve Gullion, Foughill and Carrickcarnan: an actualistic interpretation of a Tertiary gabbro-granophyre complex. Trans. Royal Soc. Edinburgh, 1xii, 85-143.

1954. Fluidization as a geological process, and its bearing on the problem of intrusive granites. Amer. Journ. Sci., cclii, 577-613.

Sabatier, G., 1956. Influence de la teneur en eau sur la viscosité d'une rétinite, verre ayant la composition chimique d'un granite. Compt. Rendu. Acad. Sci., ccxlii, 1340-1342.

SAUCIER, H., 1952. Quelques expériences sur la viscosité à haute température de verres ayant la composition d'un granite. Influence de la vapeur d'eau sous pression. Bull. Soc. franc. Min. Crist., lxxv, 1-45 and 246-294.

Grant Institute of Geology,

DORIS L. REYNOLDS.

WEST MAINS ROAD,

EDINBURGH, 9.

22nd January, 1959.

\section{MONOGRAPTUS TRIANGULATUS}

SIR,-In my paper, "Triangulate Monograptids from the Monograptus gregarius zone (Lower Llandovery) of the Rheidol Gorge (Cardiganshire)," Phil. Trans. Roy. Soc. Lond., B, 241, 485-555, 1958, I established the new species Monograptus separatus for a group of forms with rastritiform proximal thecae and triangular distal ones. Seven subspecies were distinguished, depending mainly on the number and nature of the proximal rastritiform thecae present; these were Monograptus separatus separatus Sudbury, $M$. separatus fimbriatus (Nicholson), M. separatus similis (Elles and Wood), $M$. separatus predecipiens Sudbury, $M$. separatus triangulatus (Harkness), $M$. separatus major (Elles and Wood) and $M$. separatus extremus Sudbury. My work suggested an evolutionary series in which $M$. separatus separatus was the first member and continued as the main stock, and for this reason the group as a whole was given this name.

It has been pointed out to me that according to the Rules of Zoological Nomenclature such a group must always be known by the oldest name available from among those of its members. Thus the species Monograptus separatus Sudbury, 1958, should be called Monograptus triangulatus (Harkness) 1851, and the type of the group as a whole is the specimen figured by Harkness as Rastrites triangulatus, Plate I, fig. $3 a$ (? $3 b)$ in his paper "Description of the Graptolites found in the Black Shales of Dumfriesshire", Quart. Journ. Geol. Soc., vii, 58-65. The changes of name thus required for the subspecies are listed below:- 
M. triangulatus separatus Sudbury, 1958, in place of $M$. separatus separatus.

$M$. triangulatus fimbriatus (Nicholson, 1868), in place of $M$. separatus fimbriatus.

M. triangulatus similis (Elles and Wood, 1913), in place of $M$. separatus similis.

M. triangulatus predecipiens Sudbury, 1958, in place of $M$. separatus predecipiens.

$M$. triangulatus triangulatus (Harkness, 1851), in place of $M$. separatus triangulatus.

M. triangulatus major Elles and Wood, 1913, in place of M. separatus maior.

M. triangulatus extremus Sudbury, 1958, in place of $M$. separatus extremus.

I should like to thank Prof. Dr. Bedřich Bouček for drawing my attention to this matter, and Mr. R. V. Melville for helpful discussion.

\section{Avondale RoAD, \\ MORTLAKE, \\ LONDON, S.W. 14. \\ 29th January, 1959.}

MARGARET SUdBURY.

\section{INTRUSION-BRECCIA OF DUNMORE, Co. DONEGAL}

SIR,--In a recent account of the intrusion-breccia at Dunmore, Co. Donegal, attention is drawn to the association between gas-drilled tuffisitic pipes and post-tectonic plutons (French and Pitcher, 1959). My own work in West Cork has revealed the occurrence of tuff-filled pipes penetrating folded Coomhola series sediments and raises the question of the possibility of the Southern Ireland fold belt concealing a pluton at no great depth.

The West Cork bodies, a complete description of which is in hand, have many points in common with the Dunmore breccia. The most important of these are $(a)$ the occurrence of pipes or vents with sharp and steep contacts, (b) the emplacement due to gas-stream action, and $(c)$ the petrographical similarity of texture and mineralogy of the matrices, except locally where the mineralogy is modified by the mechanical incorporation of comminuted country rock. Certain features of the West Cork bodies are not shared by any of those described intrusions which are more obviously associated with plutons. A significant fact may be that although three plug-like bodies have been recorded the bulk of the intrusions are dykes. Twenty dykes are known with a range in width from a few inches to 15 feet. All these intrusions postdate the main phase of folding. A second distinctive feature of the West Cork plugs is the heterogenity of the fragments and blocks forming the breccia. Graded zones can be defined, (a) containing blocks readily jdentified with the local succession and (b) containing exotic blocks and crystals from coarse hornblendite and calc-silicate rocks to gneisses. Single crystals of amphibole up to 6 inches in diameter occur. Thirdly, the degree of metamorphic change is minimal, suggesting that the gas was dry and not hot.

Other evidence suggestive of the proximity of a pluton in West Cork includes :-

(1) The regional metamorphism (which, although never high grade is not simply dynamic).

(2) The sulphide mineralization which elsewhere is associated with granite.

(3) The style of deformation in which cleavage folding predominates. The significance of this is discussed by L. U. de Sitter (1956).

(4) The presence of exposed granite bodies in the easterly continuation of the fold belt in South-West England. 